\title{
DETERMINATION OF HEAVY METAL ACCUMULATION IN AIR THROUGH ANNUAL RINGS: THE CASE OF MALUS FLORIBUNDA SPECIES
}

\author{
YIGIT, N. \\ Department of Forest Engineering, Faculty of Forestry, Kastamonu University \\ Kastamonu Turkey \\ (email: nyigit@kastamonu.edu.tr; phone: +90-366-280-1747; fax: +90-366-280-1700) \\ (Received $6^{\text {th }}$ Dec 2018; accepted $4^{\text {th }}$ Feb 2019)
}

\begin{abstract}
Air pollutants can be observed all over the world. Sulfur dioxide and nitrogen oxides are the most worrying ones among them. The growth rates of many forested areas in the world decrease at high altitudes, and air pollutants are more abundant as the cause of this. The leaf surface constitutes the interface between plants and the worsening atmospheric environment. Therefore, it is the first point of contact between plants and air pollutants and constitutes an effective barrier to the pollutant input. The outer surfaces of leaves are covered with a thin membrane called the cuticle. This membrane layer has many basic functions, such as preventing the excessive water loss of the plant, regulating the intake of dissolved substance and protecting photosynthetic tissues, preventing of harmful irradiation, such as improved UV-B caused by stratospheric ozone depletion. The wood structure also provides us with information on the pollutants to which they are exposed to and their levels due to the fact that trees are stationary. In this study, the accumulations of $\mathrm{Co}, \mathrm{Cu}, \mathrm{Cd}, \mathrm{Pb}, \mathrm{Ni}, \mathrm{Cr}, \mathrm{Mn}, \mathrm{Fe}, \mathrm{Al}, \mathrm{Zn}, \mathrm{Na}, \mathrm{Ca}, \mathrm{Ba}, \mathrm{Mg}$, and As elements, accumulated on the annual rings of Malus floribunda species in Ankara-Yenimahalle between 1962 and 2017, by years were determined using the GBC Integra XL-SDS-270 ICP-OES device. In conclusion, it is observed that amounts of all elements in the wood in different age ranges are statistically different at a confidence level of at least $99.9 \%$.
\end{abstract}

Keywords: wood, air pollutant, tree species, bioindicator, elements

\section{Introduction}

Toxic pollutants have increased considerably in the last century and adversely affect the lives of most living beings around them (Wolz et al., 2003; Tang et al., 2013). Trees in the settlements contribute to preventing air pollution; reducing noise, wind, dust and greenhouse effect; balancing temperature; providing energy savings and moisture; and creating habitats for fauna and flora (Cetin, 2018a, b, c, d). Environmental pollution includes the mixture of organic and inorganic compounds. Although organic components decompose harmlessly and as fully mineralized, the separation of inorganic compounds from the medium is technically difficult since do not change with a physical process (Meagher, 2000). Inorganic pollutants are basically heavy metals, such as As, $\mathrm{Ag}, \mathrm{Hg}, \mathrm{Sb}, \mathrm{Cd}$ and $\mathrm{Pb}$, containing the elements with biological functions (such as $\mathrm{Fe}$, $\mathrm{Mo}, \mathrm{Mn}, \mathrm{Zn}, \mathrm{Ni}, \mathrm{Cu}$ and $\mathrm{Co}$ ), which are harmful when they are present in excessive amounts and which do not play a known role in living organisms (DalCorso et al., 2013). Inorganic pollutants may arise from natural conditions such as the exposure of rocks to weather conditions, soil erosion, and volcanic activities or human-induced factors such as industrial or agricultural activities (Fasani et al., 2018).

Human-induced factors can be defined by the high concentration of primary pollutants such as $\mathrm{SO}_{2}$ in the air and initiate local pollution. These activities can be the cause of tree deaths, and the high level of air pollutants in neighboring areas (Garrec, 1993). 
Secondary pollutants are characterized by physiological effects, such as the yellowing of leaves and a decrease in the viability of trees as a result of the interaction of secondary pollutants with trees. These pollutants, usually along with climatic stress, initiate forest decline with a very irregular localization on a regional scale. It is necessary to consider the nature and level of these pollutants to determine the plant stress caused by air pollution. As an example of this, a summary of the scientific literature on the effects of air pollutants on epidermis characteristics during two periods was created (Table 1) (Garrec, 1993).

Table 1. The effects of air pollutants on epidermis characteristics from the scientific literature

\begin{tabular}{c|c|c|c|c|c}
\hline \multirow{2}{*}{ Air pollutant } & \multicolumn{5}{|c}{ Cuticular characteristics } \\
\cline { 2 - 6 } & Wax erosion & No wax erosion & $\begin{array}{c}\text { Increasing wax } \\
\text { amount }\end{array}$ & $\begin{array}{c}\text { Decreasing wax } \\
\text { amount }\end{array}$ & $\begin{array}{c}\text { No effect on } \\
\text { wax amount }\end{array}$ \\
\hline $\mathrm{SO} 2$ & $* * * * * * *$ & $* * * *$ & $* *$ & $* *$ & $* *$ \\
$\mathrm{O} 3$ & $* * * * *$ & $* * * * *$ & & $* *$ & $* *$ \\
Acid rain & $* * * * * *$ & $* * *$ & $*$ & $*$ & $* *$ \\
Acid mist & $* *$ & $* *$ & & & \\
$\mathrm{NH} 3$ & $* *$ & $* *$ & & & \\
\hline
\end{tabular}

*Shows the density of pollutants

The data presented in Table 1 show the variability of the response of the plant surface and/or the inhomogeneity of the action of these pollutants. Nevertheless, based on these data, primary air pollutants such as $\mathrm{SO}_{2}$ are likely to have a detrimental effect on the epidermis. Unlike the concentrated primary pollutants, secondary air pollutants such as $\mathrm{O}_{3}$ or acid deposits seem to have a less significant effect on the cuticle layer. In fact, most of the results show that the effect of these less concentrated secondary pollutants is similar to the aging process and does not have a polluting characteristic (Gunthardt-Goerg and Keller, 1987; Lutz et al., 1990).

Trees are regarded as the sensors that record environmental disturbances since they live for a long time, that remain in the same place throughout their lives and thus display chronology, and that are geographically common (Kord et al., 2009; Balouet et al., 2007). The fact that trees accumulate the heavy metals they receive from the air with the components in and above the soil makes them good indicators. Therefore, various organelles such as trunks, branches, and leaves of trees have been used for many years to determine the concentration of heavy metals in them. Leaves are the most commonly used organelles. The main reasons for this can be listed as the fact that leaves incorporate heavy metals through their stomata during photosynthesis and accumulate them, the fact that the collection of leaves does not cause permanent damage to the tree, and the fact that how long the accumulated heavy metal accumulates is known since the ages of leaves are known. Furthermore, herbarium collections (Herpin et al., 1997), the annual growth rings of trees (Watmough, 1999) also provide historical examples for bio-analysis. In fact, trees are not better indicators compared to fungi, algae, and moss. However, the use of trees throughout cities and the fact that they live longer compared to other indicator plants provide more information to scientists about the increase in heavy metal pollution in the air from past to present in the studies carried out on them (Sawidis et al., 2011; Turkyilmaz et al., 2018a; Shahid et al., 2017; Shcerbenko et al., 
2008). In recent years, many authors have reported the temporal and spatial reconstructions of heavy metals recorded on tree rings of different tree species (Aznar et al., 2008; Lageard et al., 2008; Nabais et al., 1999; Orlandi et al., 2002; Vives et al., 2005; Türkyılmaz, 2018b).

\section{Materials and methods}

The study was carried out on the wood materials obtained from Malus floribunda tree located in Yenimahalle region, which is one of the regions of Ankara province with the heaviest traffic. Ankara province has an area of $26.897 \mathrm{~km}^{2}$ and is located between $39.57 \mathrm{~N}$ latitude and $32.53 \mathrm{E}$ longitudes. Its altitude above sea level is approximately $890 \mathrm{~m}$. Ankara province is located in B4 square (Grid) according to P. H. Davis's Turkey map grid system (Davis, 1965-1985). In terms of biogeography, it is located in the Irano-Turanian floristic region. The Irano-Turanian floristic region covers the central and eastern Anatolia regions of Turkey. These regions are cold and snowy in winters and usually dry and without rain in summers (Atalay and Efe, 2014; Saya and Güney, 2014). The average temperature on a provincial scale is $11.7^{\circ} \mathrm{C}$, and the annual average precipitation is $389.1 \mathrm{~mm}$. The highest and lowest temperature values were determined to be $40.8{ }^{\circ} \mathrm{C}$ and $-24.9^{\circ} \mathrm{C}$, respectively. Upon examining the provincial center and the wind status of stations in general, the dominant wind is observed to vary depending on the land structure. Accordingly, the dominant wind blows in the northeast direction in Ankara (center), Esenboğa and Yenimahalle districts where the study area is located. The highest wind speed determined in Ankara is $29.2 \mathrm{~m} / \mathrm{s}$ (URL 1) (Fig. 1).

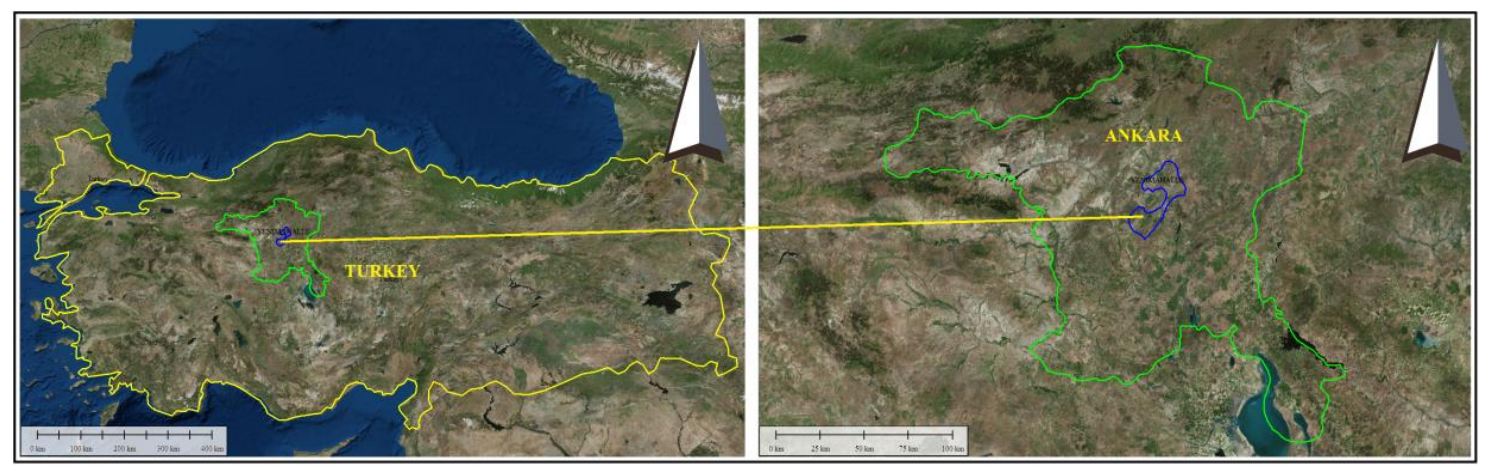

Figure 1. A map of Ankara

The samples were cut from Malus floribunda in Ankara-Yenimahalle (Turkey) in December, when the vegetation season ends, in 2017. The cut samples were brought to the laboratory and separated into pieces in the form of $1 \mathrm{~cm}$-thick discs in the laboratory environment. The sectional surfaces were made smooth by sandpapering so that annual rings could be observed clearly. During the macroscopic observation, it was determined that the tree was 55 years old, and it was decided that it was appropriate to perform grouping into five age ranges by considering the widths of annual rings. The annual rings were divided into five-year sections, and the samples taken from two opposite sides of the tree were classified. Thus, 11 samples including five-year annual rings and barks were obtained. 
The wood samples were shredded and turned into sawdust. During these processes, attention was paid to not using any tool made of the elements discussed in the study. The wood samples were first kept for 30 days until they became dry. Then, they were dried in the drying oven at $50{ }^{\circ} \mathrm{C}$ for one week. $0.5 \mathrm{~g}$ of the dried samples were taken, 6 $\mathrm{ml}$ of $65 \% \mathrm{HNO}_{3}$ and $2 \mathrm{ml}$ of $30 \% \mathrm{H}_{2} \mathrm{O}_{2}$ were added to them, and they were placed in a microwave oven. The program of the microwave device was set to $15 \mathrm{~min}$ at $200{ }^{\circ} \mathrm{C}$. After burning the samples in the microwave oven, the samples which were dissolved into solution were taken into balloons and completed to $50 \mathrm{ml}$ with ultrapure water and made ready for $\mathrm{Fe}, \mathrm{Co}, \mathrm{Ni}, \mathrm{Zn}, \mathrm{Cd}, \mathrm{Hg}$ and $\mathrm{Pb}$ analyses with the GBC Integra XL-SDS270 ICP-OES device (GBC Scientific Equipment Pty Ltd., Melbourne, Australia) For the analysis of the samples, the plasma of the ICP device was burned, and ultra-pure water was passed through the system for $15 \mathrm{~min}$ to equilibrate. The calibration chart was created by preparing standard solutions according to the elements to be analyzed. After constructing the calibration chart, the samples were given to the system and read. Since the sample was taken by $0.5 \mathrm{~g}$ and completed to $50 \mathrm{~g}$ with water, the analysis results were multiplied by 100 . Different calibration charts were created at the ppm or ppb level according to the analysis results that did not fall into the calibration chart, and reading was performed again. The detection limits for the GBC device were determined to be $(\mathrm{Pb}--->0.377 \mathrm{ppb}, \mathrm{Cu}--->0.639 \mathrm{ppb}, \mathrm{Ca}--->0.00208 \mathrm{ppm}, \mathrm{Mg}--->0.00758 \mathrm{ppm}$, Cd---> 0.063 ppb, Cr---> 0.311 ppb, Ni---> 0.171 ppb, Fe---> 0.00068 ppm, Mn---> $0.00015 \mathrm{ppm}, \mathrm{Zn}--->0.00634 \mathrm{ppm})$. In the study, all measurements were performed in three replicates. Then, the data were evaluated by the analysis of variance, Duncan's test, and correlation analysis using SPSS package program (Anonim, 1998; Eymen, 2007).

\section{Results}

A total of 15 elements were discussed for the determination of heavy metal accumulations in the wood and bark. The analysis of variance and Duncan's test were applied to the results obtained in terms of the studied elements. The average values obtained for wood and bark and the F values calculated as a result of the analysis of variance are presented in Table 2.

Based on the results summarized in Table 2, it was determined that there was no significant difference among $\mathrm{Cu}, \mathrm{Fe}, \mathrm{Ca}$ and $\mathrm{As}$ values at a confidence level of at least $95 \%$. For the rest of the elements, statistically significant differences were found between the wood and bark. According to the F values calculated, the values obtained for bark and wood were significantly different at a confidence level of $99.9 \%$ for all elements (Table 2). However, Duncan's test was not applied to determine the homogeneous group since it was performed on 2 characters including bark and wood.

The analysis of variance was performed using SPSS according to all the elements studied on annual rings in the wood sample, and the analysis result, F value, and Duncan's test results are presented in Table 3.

Upon examining Table 3, it was observed that there were significant differences at a confidence level of at least $99.9 \%$ in terms of all the characters subjected to the analysis of variance. It was determined that $\mathrm{Cu}$ value was divided into 9 different homogenous groups and that the highest value (26674.13) was reached between the years 1967-1972. Similarly, it was determined that $\mathrm{Ni}$ (1907.5), Al (2327.9), $\mathrm{Mg}$ (907.56) and $\mathrm{Zn}$ (14033.33) also had the highest values between those years. It was determined that As 
value was divided into 2 different homogenous groups and that $\mathrm{Na}, \mathrm{Ba}$, and $\mathrm{B}$ values were divided into 10 different homogenous groups. Na value was determined to be the highest (2016.6) between the years 2000 and 2005. It was determined that Mg element reached its highest value between 1955 and 1960.

Table 2. Average values obtained for wood and bark and the analysis of variance results

\begin{tabular}{c|c|c|c}
\hline Elements & Wood & Bark & F value \\
\hline Co ppb & $\mathbf{5 2 9 . 6}$ & 1229.4 & $21.807^{* * *}$ \\
Cu ppb & $\mathbf{7 7 7 9 . 2}$ & 11767.2 & $0.728 \mathrm{~ns}$ \\
Cd ppb & $\mathbf{1 7 6}$ & 330.5 & $63.992^{* * *}$ \\
Pb ppb & $\mathbf{2 0 7 7 . 4}$ & 4532.9 & $48.949^{* * *}$ \\
Ni ppb & $\mathbf{1 1 3 2 . 8}$ & 2977.7 & $86.53^{* * * *}$ \\
Cr ppb & $\mathbf{4 5 3 . 2}$ & 2154.3 & $623.793^{* * *}$ \\
Mn ppb & $\mathbf{1 0 5 8}$ & 30294.2 & $4179.785^{* * *}$ \\
Fe ppb & $\mathbf{1 8 4 4 2 . 2}$ & 29312.2 & $0.595 \mathrm{~ns}$ \\
Al ppb & $\mathbf{7 7 0 . 4}$ & 28813.1 & $4381.278^{* * *}$ \\
Zn ppb & $\mathbf{3 7 6 3}$ & 8640.8 & $2.648 * * *$ \\
Na ppm & $\mathbf{9 1 2 . 1}$ & 511.3 & $1.661 * * *$ \\
Ca ppm & $\mathbf{2 0 9 7 . 5}$ & 3218.9 & $4.385 \mathrm{~ns}$ \\
Ba ppm & $\mathbf{9 . 1}$ & 56 & $138.572^{* * *}$ \\
Mg ppm & $\mathbf{4 1 7 . 2}$ & 1767.5 & $44.028^{* * *}$ \\
As ppm & $\mathbf{1 . 6}$ & 2 & $11.656 \mathrm{~ns}$ \\
\hline
\end{tabular}

ns: Not significant

***Significant at 0.001 level

Table 3. Average values by age in wood samples and the analysis of variance results and $F$ value

\begin{tabular}{|c|c|c|c|c|c|c|c|c|c|c|c|c|}
\hline $\begin{array}{c}\text { Ages } \\
\text { Elements }\end{array}$ & $1955-1960$ & 1961-1966 & $1967-1972$ & $1973-1978$ & $1979-1984$ & $1985-1987$ & 1988-1993 & 1994-1999 & $2000-2005$ & 2006-2011 & 2012-2017 & f \\
\hline Co ppb & 800 . & $23 \mathrm{c}$ & $4 \mathrm{~d}$ & 41 & $387.07 \mathrm{ab}$ & $377.87 \mathrm{ab}$ & $.2 b$ & $419.07 \mathrm{~b}$ & $.2 \mathrm{a}$ & $356.93 \mathrm{ab}$ & $392.3 \mathrm{ab}$ & 127.727 \\
\hline $\mathrm{Cu}$ ppb & $15719.4 \mathrm{~g}$ & $16152.93 \mathrm{~h}$ & 26674.131 & $8459.5 \mathrm{f}$ & $4631.2 \mathrm{e}$ & $2409.57 \mathrm{c}$ & $2168.8 \mathrm{~b}$ & $3273.4 \mathrm{~d}$ & $1561.03 \mathrm{a}$ & $2172.9 \mathrm{~b}$ & $2348.63 \mathrm{c}$ & 35580.948 \\
\hline $\mathrm{Cd}$ ppb & $204.33 d$ & $203.27 d$ & $245.23 \mathrm{e}$ & $193.47 \mathrm{~d}$ & $175.63 \mathrm{c}$ & $167.17 \mathrm{c}$ & $166.13 \mathrm{c}$ & $163.2 \mathrm{c}$ & $148.77 \mathrm{c}$ & 137.2ab & $131.63 \mathrm{a}$ & 63.162 \\
\hline $\mathrm{Pb}$ ppb & $2769.13 c$ & $2814.73 \mathrm{c}$ & $3208.7 d$ & $2037.67 \mathrm{~b}$ & $1965.03 \mathrm{~b}$ & $1817.43 b$ & $1943.1 \mathrm{~b}$ & $1874.1 \mathrm{~b}$ & $1516.43 \mathrm{a}$ & $1448.97 \mathrm{a}$ & $1456.33 \mathrm{a}$ & 50.877 \\
\hline $\mathrm{Ni}$ ppb & $1486.5 \mathrm{~h}$ & $1419.1 \mathrm{~g}$ & 1907.51 & $1019.9 \mathrm{~d}$ & $1141.4 \mathrm{e}$ & $1200.57 f$ & $865.23 b$ & $956.2 \mathrm{c}$ & $791.8 \mathrm{a}$ & $846.9 b$ & $825.5 \mathrm{ab}$ & 563.292 \\
\hline $\mathrm{Cr} \mathrm{ppb}$ & $523.83 \mathrm{e}$ & $657.57 \mathrm{f}$ & $628.2 f$ & $485.47 \mathrm{de}$ & 463.3cde & $404.73 b c$ & $432.43 \mathrm{~cd}$ & $406.47 \mathrm{bc}$ & $330.17 \mathrm{ab}$ & $314.83 \mathrm{a}$ & $338.2 \mathrm{ab}$ & 21.291 \\
\hline $\mathrm{Mn} \mathrm{ppb}$ & 292 & $9.3 \mathrm{f}$ & $2079.73 \mathrm{~h}$ & $77 d$ & $511.8 \mathrm{c}$ & 278 & $3 \mathrm{c}$ & $1276.5 \mathrm{~g}$ & 42 & $957.6 \mathrm{e}$ & $936.47 \mathrm{e}$ & 3790.982 \\
\hline Fe ppb & $7350.6 \mathrm{c}$ & $33867 f$ & $78524 \mathrm{~h}$ & $40929.83 \mathrm{~g}$ & $27887.5 \mathrm{e}$ & $33867 d$ & $3710.66 \mathrm{~b}$ & $41.37 \mathrm{a}$ & $386.06 \mathrm{a}$ & $226.26 a$ & $254.36 \mathrm{a}$ & 46162.103 \\
\hline $\mathrm{Al} \mathrm{ppb}$ & $1837.1 \mathrm{~h}$ & $1284.73 \mathrm{~g}$ & 2327.91 & $602.03 \mathrm{e}$ & $865.23 \mathrm{f}$ & $461.53 \mathrm{~d}$ & $87.83 a$ & $349.47 \mathrm{c}$ & $58 \mathrm{a}$ & $421.17 \mathrm{~d}$ & $179.1 \mathrm{~b}$ & 1357.294 \\
\hline $\mathrm{Zn} \mathrm{ppb}$ & $13135.63 \mathrm{~h}$ & $6938.7 \mathrm{~g}$ & 14033.331 & $3663.83 \mathrm{f}$ & $1992.53 \mathrm{e}$ & 3713 & $61.03 \mathrm{a}$ & $653.76 \mathrm{~d}$ & $375.2 \mathrm{c}$ & $147.6 \mathrm{~b}$ & $20.1 \mathrm{a}$ & 75236.672 \\
\hline $\mathrm{Na}$ ppm & $521.06 \mathrm{c}$ & $422.23 b$ & $868.5 f$ & $841.33 \mathrm{e}$ & $1016.8 \mathrm{~g}$ & $1198.26 \mathrm{~h}$ & 1716.031 & $360.36 \mathrm{a}$ & 2016.6j & $719.6 \mathrm{~d}$ & $352.3 \mathrm{a}$ & 28471.922 \\
\hline Ca ppm & $3250.4 \mathrm{~g}$ & $2914.96 \mathrm{e}$ & $3136.86 \mathrm{f}$ & $1955.93 \mathrm{~d}$ & $1956.7 d$ & $1982 d$ & $1974.83 d$ & $3247.1 \mathrm{~g}$ & $1073.93 \mathrm{c}$ & $823.36 b$ & $756.7 \mathrm{a}$ & 12064.255 \\
\hline Ba ppm & $25.9 \mathrm{j}$ & $10.93 \mathrm{~h}$ & 17.71 & $10.2 \mathrm{~g}$ & $7.8 \mathrm{f}$ & $4.66 \mathrm{~d}$ & $6.13 \mathrm{e}$ & $6.033 \mathrm{e}$ & $4.4 \mathrm{c}$ & $3.36 \mathrm{~b}$ & $2.8 \mathrm{a}$ & 21305.217 \\
\hline $\mathrm{Mg} \mathrm{ppm}$ & $1227.3 \mathrm{k}$ & 4991 & $907.56 \mathrm{j}$ & $174.4 \mathrm{~h}$ & $466 \mathrm{~g}$ & $220.4 f$ & $174.4 \mathrm{~d}$ & $186.33 \mathrm{e}$ & $119.03 \mathrm{a}$ & $144.7 \mathrm{~b}$ & $160.2 \mathrm{c}$ & 54894.807 \\
\hline As ppm & $1.9 \mathrm{~b}$ & $1.83 \mathrm{~b}$ & $1.83 \mathrm{~b}$ & 1.5 & $1.53 \mathrm{a}$ & $1.46 \mathrm{a}$ & $1.46 \mathrm{a}$ & $1.53 \mathrm{a}$ & $1.5 \mathrm{a}$ & $1.46 \mathrm{a}$ & $1.53 \mathrm{a}$ & 9.745 \\
\hline
\end{tabular}

The graphics, which were prepared to make the changes associated with heavy metals according to the ages more clearly understandable, are presented in Figure 2. 


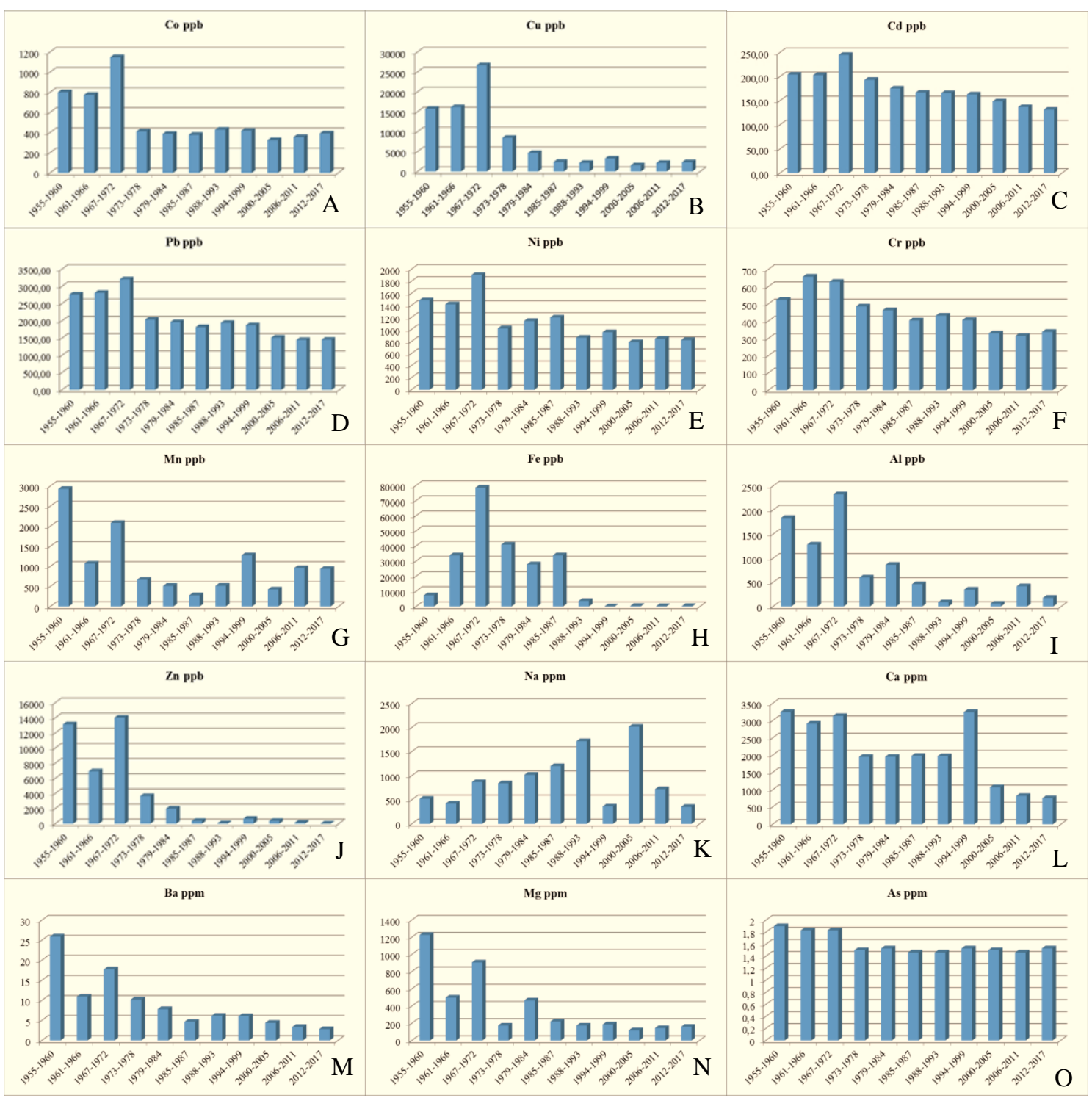

Figure 2. Annual changes in heavy metal concentrations over years (A changes in Co concentrations, $B$ changes in Cu concentrations, $C$ changes in $C d$ concentrations, $D$ changes in $\mathrm{Pb}$ concentrations, E changes in Ni concentrations, $F$ changes in $C r$ concentrations, $G$ changes in Mn concentrations, $H$ changes in Fe concentrations, I changes in Al concentrations, $J$ changes in Zn concentrations, $K$ changes in Na concentrations, $L$ changes in $C A$ concentrations, $M$ changes in Ba concentrations, $N$ changes in $M g$ concentrations, $O$ changes in As concentrations

As seen in Figure 2, especially $\mathrm{Pb}, \mathrm{Cu}, \mathrm{Co}, \mathrm{Mg}$ and $\mathrm{Ba}$ elements were found to decrease after 1979-1984 years. One of the reasons for this could be the use of natural gas in Ankara since the 1980s.

As a result of the study, correlation analysis was performed to determine the relationships between the elements and the results are presented in Table 4. The studied relationship that was not measured in the correlation analysis is related to the linear part of the relationship between the variables. The correlation coefficient calculated as a result of the correlation analysis is indicated with $r$ and takes values between -1 and +1 . The fact that the coefficient is close to +1 indicates that there is a good correlation 
between the two variables, and the fact that it is close to -1 indicates that there is a good but inverse correlation; in other words, one of the variables increases while the other one decreases. Upon evaluating the results in this respect, it is observed that the level of relationship between some elements is really high.

Table 4. Correlation analysis results

\begin{tabular}{l|c|c|c|c|c|c|c|c|c|c|c|c|c|c}
\hline & Cu ppb & Cd ppb & Pb ppb & Ni ppb & Cr ppb & Mn ppb & Fe ppb & Al ppb & Zn ppb & Na ppm & Ca ppm & Ba ppm & Mg ppm & As ppm \\
\hline Co ppb & $.839^{* *}$ & $.906^{* *}$ & $.940^{* *}$ & $.914^{* *}$ & $.754^{* *}$ & $.675^{* *}$ & $.649^{* *}$ & $.686^{* *}$ & $.867^{* *}$ & $-.365^{*}$ & $.714^{* *}$ & $.830^{* *}$ & $.877^{* *}$ & $.867^{* *}$ \\
\hline Cu ppb & & $.648^{* *}$ & $.691^{* *}$ & $.615^{* *}$ & $.330^{*}$ & .208 & $.826^{* *}$ & .227 & $.945^{* *}$ & $-.345^{*}$ & $.681^{* *}$ & $.482^{* *}$ & $.649^{* *}$ & $.744^{* *}$ \\
\hline Cd ppb & & & $.973^{* *}$ & $.968^{* *}$ & $.904^{* *}$ & $.835^{* *}$ & $.597^{* *}$ & $.850^{* *}$ & $.710^{* *}$ & -.266 & $.701^{* *}$ & $.929^{* *}$ & $.917^{* *}$ & $.755^{* *}$ \\
\hline Pb ppb & & & & $.957^{* *}$ & $.881^{* *}$ & $.803^{* *}$ & $.556^{* *}$ & $.815^{* *}$ & $.755^{* *}$ & $-.334^{*}$ & $.735^{* *}$ & $.917^{* *}$ & $.919^{* *}$ & $.846^{* *}$ \\
\hline Ni ppb & & & & & $.924^{* *}$ & $.875^{* *}$ & $.523^{* *}$ & $.889^{* *}$ & $.692^{* *}$ & $-.332^{*}$ & $.650^{* *}$ & $.943^{* *}$ & $.925^{* *}$ & $.769^{* *}$ \\
\hline Cr ppb & & & & & & $.979^{* *}$ & .294 & $.986^{* *}$ & $.428^{* *}$ & -.273 & $.486^{* *}$ & $.939^{* *}$ & $.833^{* *}$ & $.635^{* *}$ \\
\hline Mn ppb & & & & & & & .154 & $.998^{* *}$ & $.341^{*}$ & -.259 & $.389^{*}$ & $.927^{* *}$ & $.799^{* *}$ & $.560^{* *}$ \\
\hline Fe ppb & & & & & & & & .195 & $.673^{* *}$ & -.148 & $.463^{* *}$ & .322 & $.452^{* *}$ & $.448^{* *}$ \\
\hline Al ppb & & & & & & & & & $.349^{*}$ & -.246 & $.394^{*}$ & $.926^{* *}$ & $.801^{* *}$ & $.563^{* *}$ \\
\hline Zn ppb & & & & & & & & & & $-.350^{*}$ & $.720^{* *}$ & $.642^{* *}$ & $.805^{* *}$ & $.818^{* *}$ \\
\hline Na ppm & & & & & & & & & & & $-.392^{*}$ & -.312 & $-.370^{*}$ & $-.429^{* *}$ \\
\hline Ca ppm & & & & & & & & & & & $.603^{* *}$ & $.671^{* *}$ & $.674^{* *}$ \\
\hline Ba ppm & & & & & & & & & & & & & $.961^{* *}$ & $.745^{* *}$ \\
\hline Mg ppm & & & & & & & & & & & & & & $.815^{* *}$ \\
\hline
\end{tabular}

Upon examining Table 4, it is observed that there is a positive correlation in general with respect to the measured characters. When the results are examined in this context, the relationship between some elements is observed to be quite high. For example, the correlation coefficients between $\mathrm{Cr}$ and $\mathrm{Al}$ (0.986), $\mathrm{Mn}$ and $\mathrm{Al}(0.998)$ and $\mathrm{Cr}$ and $\mathrm{Mn}$ (0.979) are quite high. Similarly, the correlation coefficient calculated between $\mathrm{Na}$ and As $(-0.429)$ is negative but very strong. Furthermore, very strong relationships were observed among many elements (Table 4).

\section{Discussion and conclusion}

The results of the study reveal that the concentration of all heavy metals that adversely affect human health increases with age. It can be said that the increase in the amount of heavy metals in tree rings is due to the morphological structure of the tree and ecological impacts, which does not exhibit a linear increase, high in some years and low in other years. The morphological structure of the epidermis layer varies by age and polluted air (Huttunen and Laine, 1983; Mengel et al., 1989; Turunen and Huttunen, 1990). Similar results were also obtained in the studies carried out on different species (Beramendi-Orosco et al., 2013; Türkyılmaz et al., 2018c, 2019). In the study carried out by Beramendi-Orosco (2013): on Prosopis julifora annual rings, the researchers ported that the amount of $\mathrm{Cu}$, which was 1.09 ppm during 1988-1992, was $1.27 \mathrm{ppm}$ during 2003-2007 and that the amount of Pb, which was 0.35 ppm during 1998-2002, was $0.46 \mathrm{ppm}$ during 1993-1997. Similar results were also obtained in the studies in which changes were determined by months (Norouzi et al., 2015).

When tree annual rings were examined, it was determined that heavy metal accumulation was intense in the early years in elements such as $\mathrm{Cd}, \mathrm{Pb}, \mathrm{Al}, \mathrm{Zn}, \mathrm{Mg}, \mathrm{Ca}$ and B. However, there is no clear evidence on whether this intensity was due to the accumulation during the first years of the tree or the accumulation of all years. As seen 
in Figure 2, especially $\mathrm{Pb}, \mathrm{Cu}, \mathrm{Co}, \mathrm{Mg}$ and $\mathrm{Ba}$ elements were found to decrease after 1979-1984. One of the reasons for this could be the use of natural gas in Ankara since the 1980s.

Although some elements such as $\mathrm{K}, \mathrm{S}, \mathrm{Mg}, \mathrm{CI}$, and $\mathrm{P}$ can be transported to the plant's metabolic activities, the transport of certain elements in the phloem $(\mathrm{B}, \mathrm{Ba}, \mathrm{Ca}, \mathrm{Cu}, \mathrm{Fe}$, $\mathrm{Li}, \mathrm{Mn}, \mathrm{Mo}$, and $\mathrm{Zn}$ ) is more limited (Perone et al., 2018). In recent years, the nature and intensity of the concentration of elements in nature have increased due to the increase in human effects and vehicle traffic. Some data indicate that climate change is affected not only by the traces of pollution but also by plant metabolism and by the distribution of elements in plants (Cui et al., 2013; Li et al., 2004). Nowadays, in the world, motor vehicles exhausts, industrial activities, mineral deposits and enterprises, use of urban wastes as fertilizers, chemical fertilizers and pesticide applications, and reach a significant amount of heavy metal soil. The accumulation of heavy metals in the soil not only affects soil fertility and ecosystem activities, but also affects many metabolic events such as photosynthesis, respiration, growth and development within the plant and therefore affects animal health and human health significantly due to deteriorated food chain. In the soils where heavy metal accumulation is observed, heavy metals reach the human body through the skin contact of people, breathing, growing vegetables and fruits. For this reason, heavy metal that can be harmful to human health, etc. the means of transmission and prevention of all kinds of substances should be investigated.

\section{REFERENCES}

[1] Anonymous (1998): SPSS (Statistical Package for Social Sciences), Relase 90.0. - IBM, Armonk, NY.

[2] Atalay, I., Efe, R. (2015): Biogeography of Turkey. - Meta Press, İzmir (in Turkish).

[3] Aznar, J. C., Richer-Laflèche, M., Bégin, C., Rodriguez, R. (2008): Spatiotemporal reconstruction of lead contamination using tree rings and organic soil layers. - Science of the Total Environment 407: 233-241.

[4] Beramendi-Orosco, L. E., Rodriguez-Estrada, M. L., Morton-Bermea, O., Romero, F., M., Gonzalez-Hernandez, G., Hernandez-Alvarez, E. (2013): Correlations between metals in tree-rings of Prosopis julifora as indicators of sources of heavy metal contamination. Applied Geochemistry 39: 78-84.

[5] Balouet, J. C., Oudijk, G., Smith, K. T., Petrisor, I., Grudd, H., Stocklassa, B. (2007): Applied dendroecology and environmental forensics. Characterizing and age dating environmental releases: fundamentals and case studies. - Environmental Forensics 8: 117.

[6] Cetin, M., Sevik, H., Yigit, N. (2018a): Climate type-related changes in the leaf micromorphological characters of certain landscape plants. - Environmental Monitoring and Assessment 190: 404. https://doi.org/10.1007/s10661-018-6783-3.

[7] Cetin, M., Sevik, H., Yigit, N., Ozel, H. B., Aricak, B., Varol, T. (2018b): The variable of leaf micromorphogical characters on grown in distinct climate conditions in some landscape plants. - Fresenius Environmental Bulletin 27(5): 3206-3211.

[8] Cetin, M., Sevik, H., Canturk, U., Cakir, C. (2018c): Evaluation of the recreational potential of Kutahya Urban Forest. - Fresenius Environmental Bulletin 27(5): 2629-2634.

[9] Cetin, M., Zeren, I., Sevik, H., Cakir, C., Akpinar, H. (2018d): A study on the determination of the natural park's sustainable tourism potential. - Environmental Monitoring and Assessment 190(3): 167. https://doi.org/10.1007/s10661-018-6534-5. 
[10] Cui, M., He, X., Davi, N., Chen, Z., Zhang, X., Peng, J., Chen, W. (2013): Evidence of century-scale environmental changes: trace element in tree-ring from Fuling Mausoleum $\begin{array}{lllll}\text { Shenyang, } & \text { China. } & - & \text { Dendrochronologia } & 31(1):\end{array}$ https://doi.org/10.1016/j.dendro.2011.09.003.

[11] DalCorso, G., Manara, A., Furini, A. (2013): An overview of heavy metal challenge in plants: from roots to shoots. - Metallomics 5: 1117-1132.

[12] Davis, P. H. (1965-1985): Flora of Turkey and the East Aegean Islands. Vol. 1-9. Edinburg University Press, Edinburgh.

[13] Gunthardt-Goerg, M. S., Keller, T. (1987): Some effects of long-term ozone fumigation on Norway spruce. II. Epicuticular wax and stomata. - Trees 1: 145-150.

[14] Eymen, U. E. (2007): SPSS Kullanma Kilavuzu. - İstatistik Merkezi, Istanbul.

[15] Fasani, E., Manara, A., Martini, F., Furini, A., DalCorso, G. (2018): The potential of genetic engineering of plants for the remediation of soils contaminated with heavy metals. - Plant, Cell and Environment 41: 1201-1232. DOI: 10.1111/pce.12963.

[16] Herpin, U., Markert, B., Weckert, V., Berlekamp, J., Friese, K., Siewers, U., Lieth, H. (1997): Retrospective analysis of heavy metal concentrations at selected locations in the Federal Republic of Germany using moss material from a herbarium. - The Science of Total Environment 205: 1-12.

[17] Huttunen, S., Laine, K. (1983): Effects of air-borne pollutants on the surface wax structure of Pinus sylvestris needles. - Ann Bot Fennici 20: 79-86.

[18] Kord, B.; Mataji, A.; Babaie, S. (2009): Pine (Pinus eldarica Medw.) needless as indicator for heavy metals pollution. - Int. J. Environment Sci. Tech. 7(1): 79-84.

[19] Lageard, J. G. A., Howell, J. J., Rothwell, B., Drew, I. B. (2008): The utility of Pinus sylvestris $\mathrm{L}$. in dendrochemical investigations: pollution impact of lead mining and smelting in Darley Dale, Derbyshire. - Environmental Pollution 153: 284-294.

[20] Li, X., Lee, S., Wong, S., Shi, W., Thornton, I. (2004): The study of metal contamination in urban soils of Hong Kong using a GIS-based approach. - Environmental Pollution 129: 113-124.

[21] Lutz, C., Heinzmann, V., Giilz, P. G. (1990): Surface structures and epicuticular wax composition of spruce needles after long term treatment with ozone and acid mist. Environ Poll 64: 313-322.

[22] Meagher, R. B. (2000): Phytoremediation of toxic elemental and organic pollutants. Current Opinion in Plant Biology 3: 153-162.

[23] Mengel, K., Hogrebe, A. M. R., Esch, A. (1989): Effect of acidic fog on needle surface and water relations of Picea abies. - Physiol Plant 75: 201-207.

[24] Nabais, C., Freitas, H., Hagemeyer, J. (1999): Dendroanalysis: a tool for biomonitoring environmental pollution? - Science of the Total Environment 232: 33-37.

[25] Norouzi, S., Khademi, H., Cano, A. F., Acosta, J. A. (2015): Using plane tree leaves for biomonitoring of dust borne heavy metals: A case study from Isfahan, Central Iran. Ecological Indicators 57: 64-73.

[26] Orlandi, M., Pelfini, M., Pavan, M., Santilli, M., Colombini, M. P. (2002): Heavy metals variations in some conifers in Valle d'Aosta (Western Italian Alps) from 1930 to 2000. Microchemical journal 73: 237-244.

[27] Perone, A., Cocozza, C., Cherubini, P., Bachmann, O., Guillong, M., Lasserre, B., Marchetti, M., Tognetti, R. (2018): Oak tree-rings record spatial-temporal pollution trends from different sources in Terni (central Italy). - Environmental Pollution 233: 278289. https://doi.org/10.1016/j.envpol.2017.10.062.

[28] Garrec, J. P. (1993): Cuticular Characteristics in the Detection of Plant Stress Due to Air Pollution. - New Problems in the Use of these Cuticular Characteristics. - In: Percy, K. E., Cape, J. N., Jagels, R., Simpson, C. J. (eds.) Air Pollutants and Leaf Cuticle. https://doi.org/10.1007/978-3-642-79081-2_9. 
[29] Sawidis, T., Breuste, J., Mitrovic, M., Pavlovic, P., Tsigaridas, K. (2011): Trees as bioindicator of heavy metal pollution in three European cities. - Environmental Pollution 159(12): 3560-3570.

[30] Saya, Ö., Güney, S. (2014): Türkiye Bitki coğrafyas1, Çevre ve yer Bilimi: 004, Yayın No: 964. - Nobel Yayıncilık, Ankara.

[31] Shahid, M., Dumat, C., Khalida, S., Schreck, E., Xiong, T., Nabeel Khan Niazi, N. K. (2017): Foliar heavy metal uptake, toxicity and detoxification in plants: a comparison of foliar and root metal uptake. - Journal of Hazardous Materials 325: 36-58.

[32] Shcherbenko, T. A., Koptsik, G. N., Groenenberg, B. J., Lukina, N. V., Livantsova, S., Y. (2008): Uptake of nutrients and heavy metals by pine trees under atmospheric pollution. Moscow University Soil Science Bulletin 63(2): 51-59. DOI: 10.3103/S0147687408020026.

[33] Tang, Q., Liu, G., Zhou, C., Zhang, H., Sun, R. (2013): Distribution of environmentally sensitive elements in residential soils near a coal-fired power plant: potential risks to ecology and children's health. - Chemosphere 93: 2473-2479.

[34] Turkyilmaz, A., Sevik, H., Cetin, M. (2018a): The use of perennial needles as biomonitors for recently accumulated heavy metals. - Landscape and Ecological Engineering 14(1): 115-120. DOI: 10.1007/s11355-017-0335-9.

[35] Turkyilmaz, A., Sevik, H., Cetin, M., Saleh, E. A. A. (2018b): Changes in heavy metal accumulation depending on traffic density in some landscape plants. - Polish Journal of Environmental Studies 27(5): 2277-2284. DOI: 10.15244/pjoes/78620.

[36] Turkyilmaz, A., Sevik, H., Isınkaralar, K., Cetin, M. (2018c): Using Acer platanoides annual rings to monitor the amount of heavy metals accumulated in air. - Environ Monit Assess 190: 578. https://doi.org/10.1007/s10661-018-6956-0.

[37] Turkyilmaz, A., Sevik, H., Cetin, M., Isinkaralar, K. (2019): Use of tree rings as a bioindicator to observe atmospheric heavy metal deposition. - Environment, Development and Sustainability. https://doi.org/10.1007/s11356-018-3962-2.

[38] Turunen, M., Huttunen, S. (1990): A review of the response of epicuticular wax of conifer needles to air pollution. - J Environ Qual 19: 35-45.

[39] URL 1. http://www.ankara.gov.tr/iklimi. - Erişim tarihi 09/11/2018.

[40] Vives, A. E. S., Silva, R. M. C., Medeiros, J. G. da S., Tomazello-Filho, M., Barroso, R. C., Zucchi, O. L. A. D., Moreira, S. (2005): Accumulation of elements in annual tree rings measured by synchrotron x-ray fluorescence analysis. - X-Ray Spectrometry 34: 411-416.

[41] Watmough, S. A. (1999): Monitoring historical changes in soil and atmospheric trace metal levels by dendrochemical analysis. - Environmental Pollution 106: 391-403. DOI: 10.1016/S0269-7491(99)00102-5.

[42] Wolz, S., Fenske, R. A., Simcox, N. J., Palcisko, G., Kissel, J. C. (2003): Residential arsenic and lead levels in an agricultural community with a history of lead arsenate use. Environmental Research 93: 293-300. 